\title{
Performance of ground anchors in a Mass Rapid Transit project in Malaysia
}

\author{
CW Boon MMC-Gamuda KVMRT (T) Sdn Bhd, Malaysia \\ LH Ooi MMC-Gamuda KVMRT (T) Sdn Bhd, Malaysia \\ YY Low MMC-Gamuda KVMRT (T) Sdn Bhd, Malaysia
}

\begin{abstract}
Ground anchors are widely used in excavation projects in soil as active support members with pre-stressed loads. The pre-stressed loads are prescribed by the designers, and these loads are introduced to the tendons through hydraulic jacks during installation. During construction, these loads are being monitored via load cells which are installed at several selected ground anchors. This paper shows the data collected from the construction of several underground stations in a Mass Rapid Transit (MRT) project in Malaysia in which ground anchors have been used as temporary supports for the deep excavations. The prescribed lock-off loads are compared with the load cell measurements immediately after lock-off. There are two geological formations where the ground anchors were employed, namely the Kenny Hill Formation consisting of weathered meta-sedimentary rocks, and the Kuala Lumpur Limestone rock formation where the overburden above the rock head consists of alluvial deposit or mine tailings. It is found that the scatter varies between the ground anchors installed at different stations, some of which show distinct bell-shaped probabilistic distributions. Several potential sources of scatter are discussed.
\end{abstract}

\section{Introduction}

Ground anchors are performance based support elements for temporary walls in deep excavations. An onsite acceptance test is carried out for every ground anchor after installation. After that, a few ground anchors are selected for monitoring using vibrating-wire load cells to ensure that the service loads are maintained and within both the geotechnical and structural capacity, i.e. that they are within design predictions. The installation is as follows: a load cell is placed below the anchor block, and the tendons are stressed using a hydraulic jack to the prescribed lock-off load (or in practice to a site acceptance load and subsequently unloaded to the prescribed lock-off load). Upon achieving the desired loads, wedges are inserted into the holes of the anchor blocks before the loads of the hydraulic jack are released.

Temporary U-loop ground anchors (see Figures $1(\mathrm{a})$ and (b)) were used in several deep excavations of underground stations in the MRT project in this study. The MRT project site consists of two geological formations; the first is the Kenny Hill Formation consisting of weathered meta-sedimentary rocks; the second is the Kuala Lumpur Limestone rock formation where the overburden above the rock head consists of alluvial deposit or mine tailings. The unit fixed length for each loop into the limestone formation is $1.5 \mathrm{~m}$ (see Figure 1(b)).

In the U-loop temporary ground anchor, the tendons are fully sleeved and greased inside a plastic sheath, and the borehole is fully grouted. Ground anchors with several U-loops of different unit lengths were used in the sites. Ideally stressing should be carried out using a multiple jack system. However, stressing was carried out using hollow jacks. Due to displacement compatibility when using hollow jacks on multi-loop anchors, the tendons with longer lengths require pre-stressing to a predetermined magnitude, before stressing the shorter tendons (while at the same time still stressing the longer tendons); this is an approximate attempt to achieve the same working loads across all the tendons belonging to different U-loops. The apparent free length was also calculated to confirm that it falls between 90 and $110 \%$ of the 
design free length. The apparent free length, $L_{a}$, of a ground anchor with $N$ number of U-loops can be estimated as (see Figure 1):

$$
L_{a}=\frac{N}{\frac{1}{L_{i}}+\frac{1}{L_{i+1}}+\ldots+\frac{1}{L_{i+N}}}
$$

where:

$$
L_{i} \quad=\text { unit length of the } i^{\text {th }} \mathrm{U} \text {-loop. }
$$

An example of the onsite acceptance test for a 2 loop U-turn anchor of working load of $300 \mathrm{kN}$ is shown in Figures 2(a) and (b). The test load as per British Standard (1989) (BS8081) is up to $125 \%$ over two cycles. In the two cycles, the tendons were stressed up to $125 \%$ working load according to Clause 11.4 .3 for the case of a temporary ground anchor in BS8081 and held for 15 minutes. The acceptance as per Clause 11.4.6 is a load loss of less than $1 \%$ per time interval specified ( 5 and 15 mins). The load-displacement hystereses observed is typical of a ground anchor test and likely due to the stressing and anchor system response during load/unload cycles. The tendons are essentially elastic and no slippage is taking place. The calculation to check for the structural capacity of a strand is shown in Table 1.

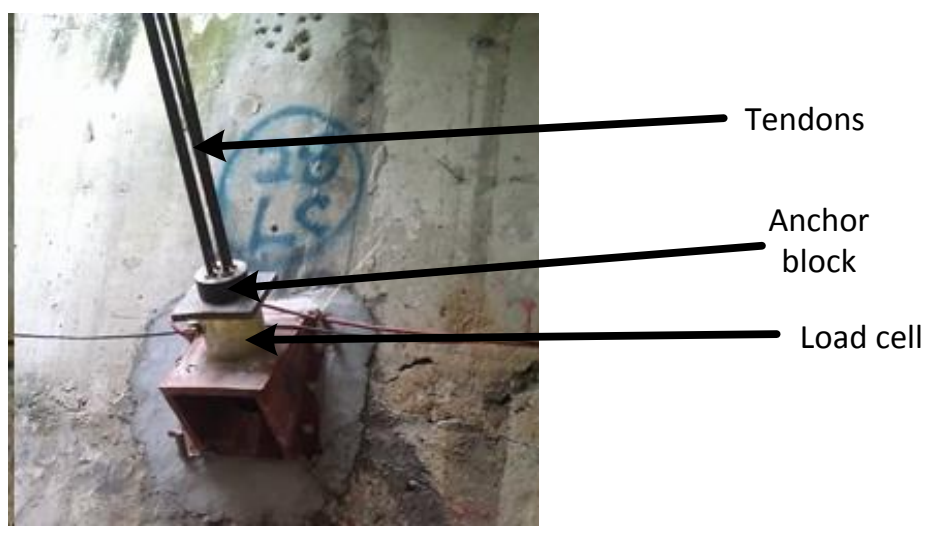

(a)

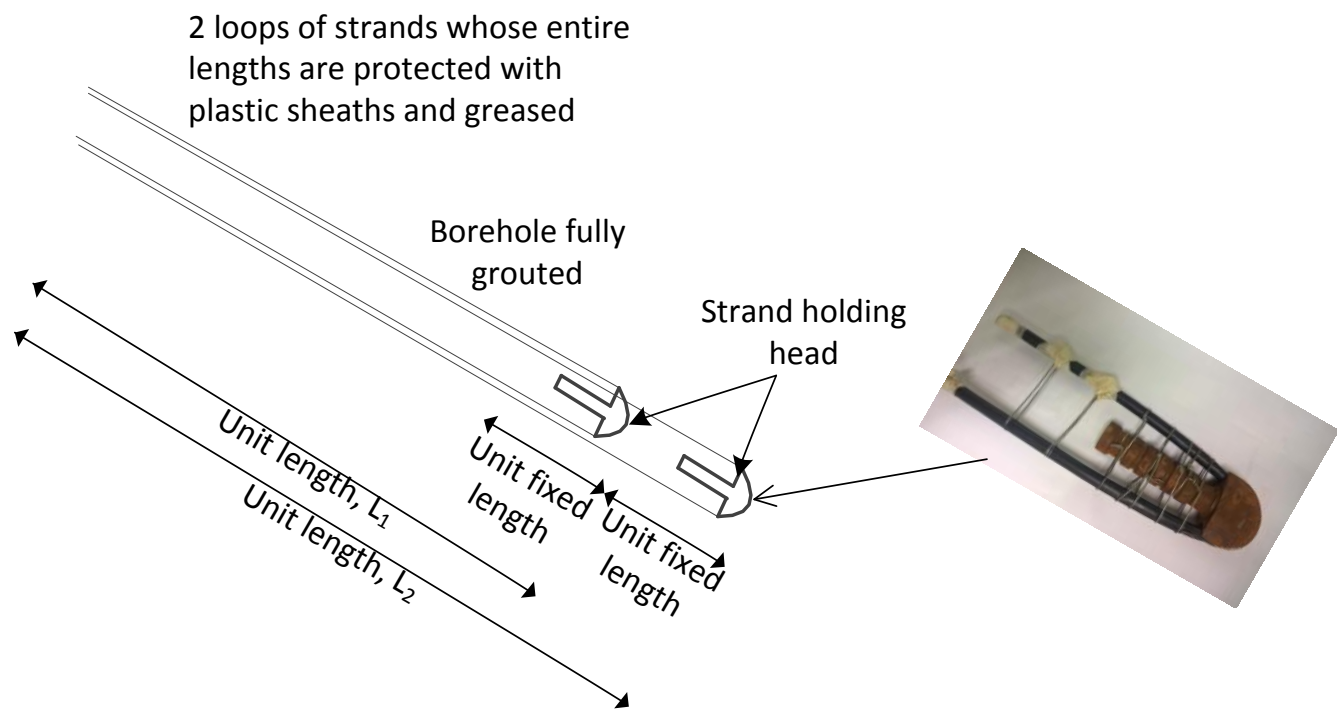

(b)

Figure 1 Temporary U-loop ground anchor; (a) image of instrumented ground anchor installed in the Kenny Kill formation; and (b) a schematic illustration of the tendons in soil (not to scale) 
Table 1 Structural capacity of a strand in the ground anchor in Figure 2

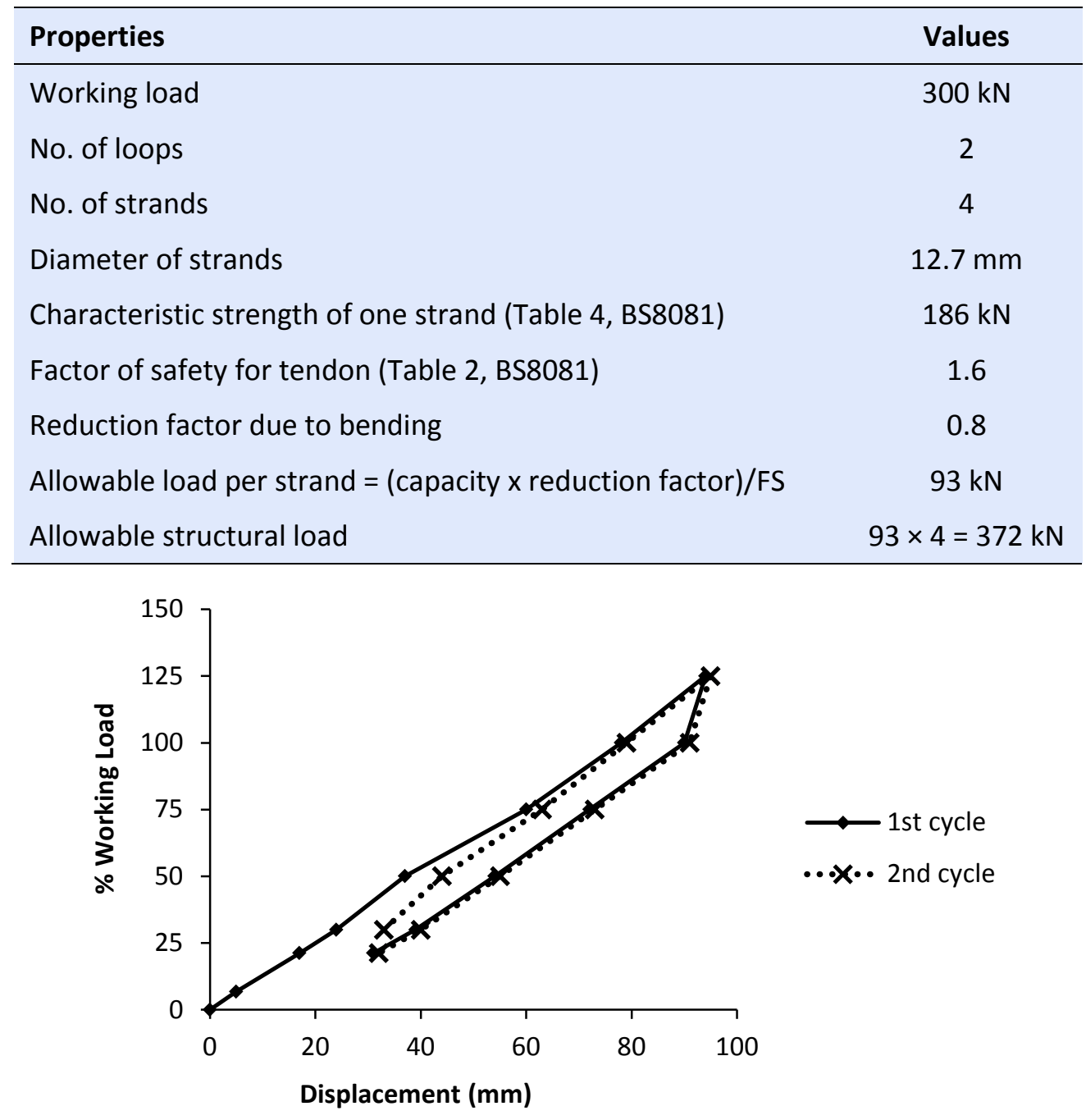

(a)

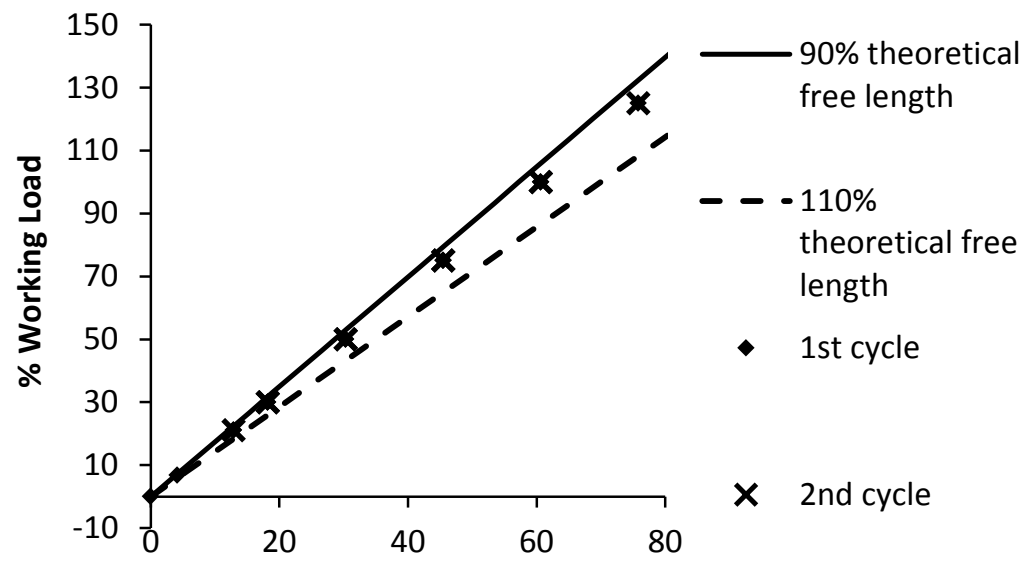

Elastic displacement (mm)

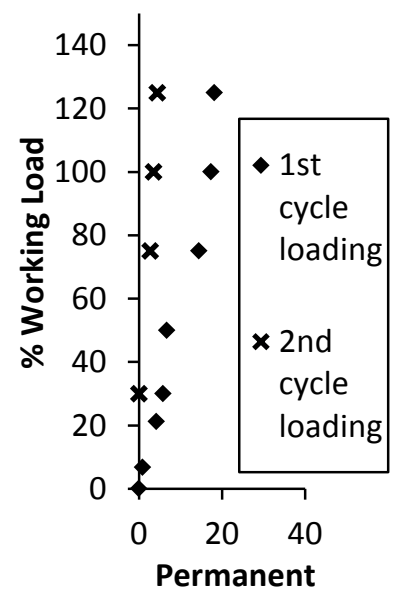

displacement $(\mathrm{mm})$

(b)

Figure 2 An example of an onsite acceptance test for the U-loop temporary ground anchor; (a) stressing up to $125 \%$ working load; and (b) checking of free lengths (as per Figure 34 of BS8081) 


\section{$2 \quad$ Prescribed lock-off loss and monitored readings in load cell}

The monitored load cell readings are compiled and compared with the prescribed lock-off loads for the different stations. Note that the jack loads were utilised as reference loads for lock-off. The results for the ground anchors in Stations A, B and C in the Kenny Hill Formation are shown in Figure 3, whereas the results for the ground anchors in Stations D, E, F and G in the Kuala Lumpur Limestone Formation are shown in Figure 4. There are several reasons which could create the discrepancies. The first is due to genuine lock-off loss, which is implied to be approximately $10 \%$ according to British Standards (8081). The second is an error in the monitored load cell readings due to non-concentric loading conditions.

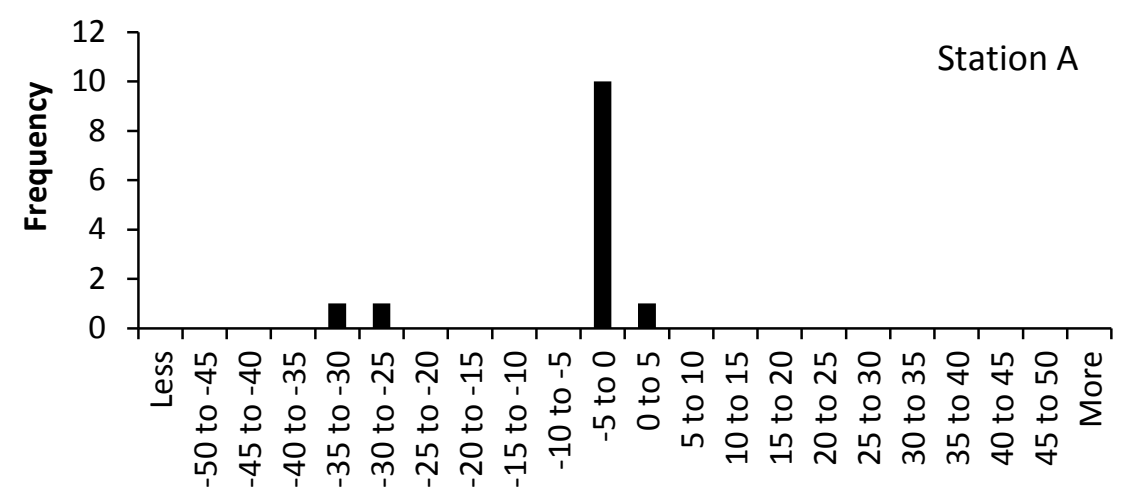

(a)

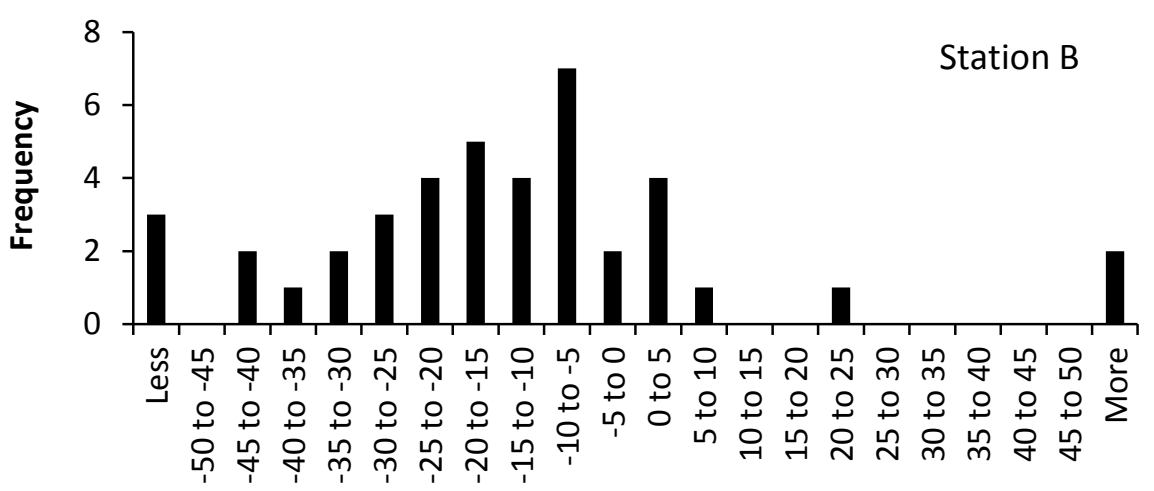

(b)

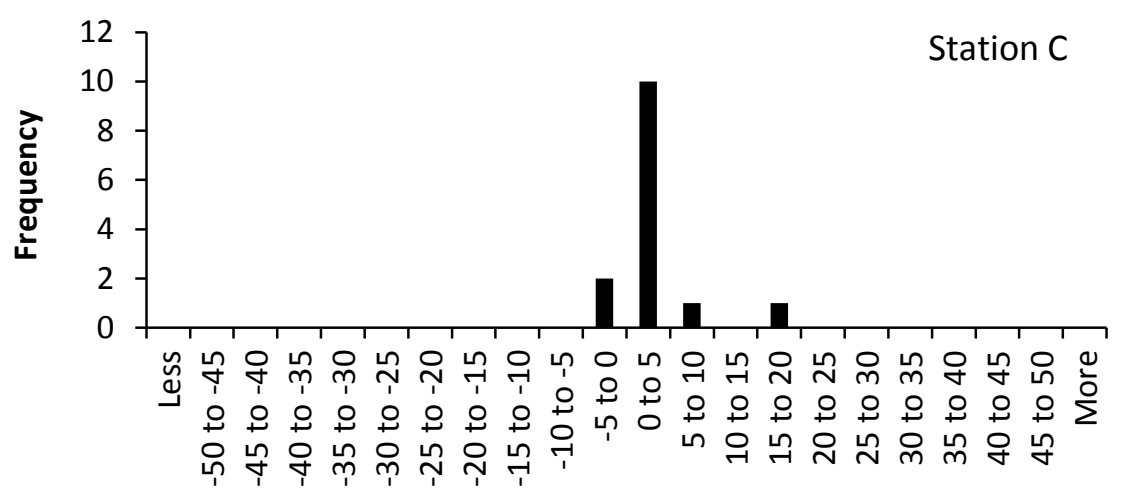

(c)

Figure 3 Histogram for (monitored load after lock-off - prescribed lock-off)/(prescribed lock-off ) $\times 100 \%$ for ground anchors in the Kenny Hill Formation; (a) Station A (range of $P_{\text {lock-off }}=533-825 \mathrm{kN}$ ); (b) Station B (range of $P_{\text {lock-off }}=215-1,020 \mathrm{kN}$ ); and (c) Station C (range of $P_{\text {lock-off }}=99-1,727 \mathrm{kN}$ ). Note that the units in the $\mathrm{x}$ axis are in terms of percentage discrepancy 


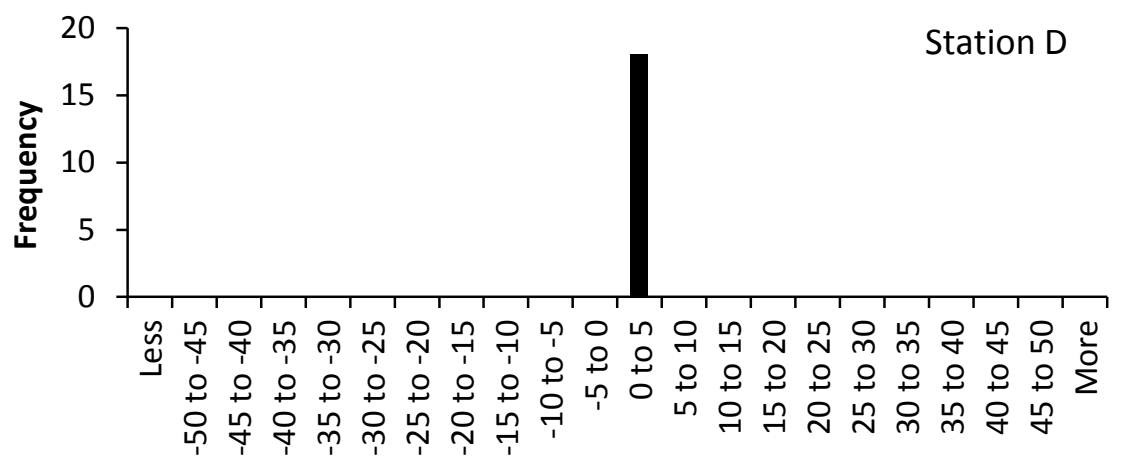

(a)

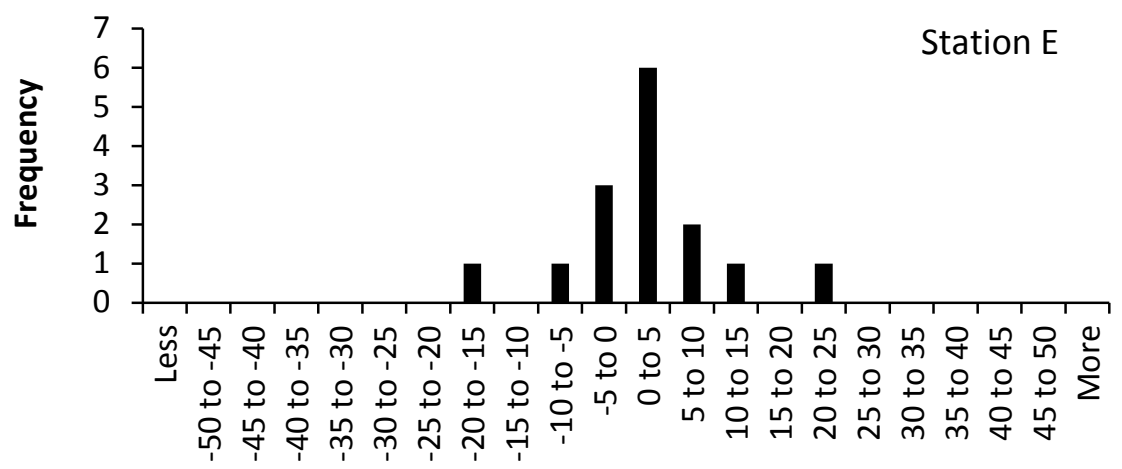

(b)

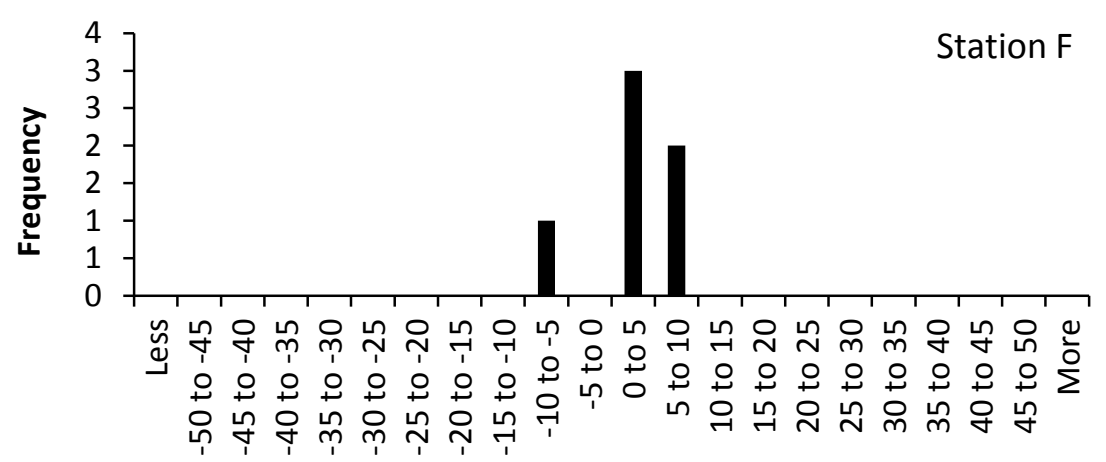

(c)

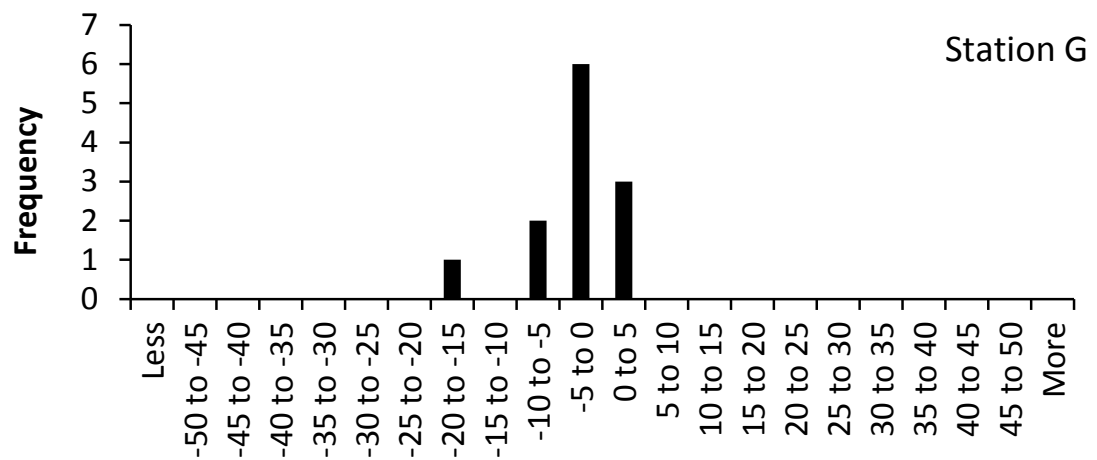

(d)

Figure 4 Histogram for (monitored load after lock-off - prescribed lock-off)/(prescribed lock-off ) $\times 100 \%$ for ground anchors in the Kuala Lumpur Limestone rock formation; (a) Station D (range of $P_{\text {lock-off }}=72-933 \mathrm{kN}$ ); (b) Station E (range of $P_{\text {lock-off }}=279-815 \mathrm{kN}$ ); (c) Station F (range of $\left.P_{\text {lock-off }}=373-860 \mathrm{kN}\right)$; (d) Station G (range of $P_{\text {lock-off }}=141-651 \mathrm{kN}$ ) 


\subsection{Discussion on the ground anchors in the Kenny Hill formation}

For the ground anchors installed in the Kenny Hill formation (Figure 3), most of the deviations between measured load cell readings and prescribed lock-off loads in Stations A and C are within $\pm 10 \%$. As a benchmark, note that BS8081 recommends that the lock-off load is $110 \%$, implying that a loss of approximately $10 \%$ during lock-off is expected. The two discrepancies in Station A (-27 and $-31 \%)$ were later found to be caused respectively by a malfunctioning strain gauge in the load cell, and an actual case where creep was observed subsequently. The specific anchor had to be downgraded to carry a lower working load.

The scatter of the discrepancies Station B is significant, showing a distinct trend in terms of probabilistic distributions, skewed toward the losses (negative values). That is to say, some of the ground anchors were unable to maintain the lock-off loads and experienced losses immediately. A review was carried out, and the ground anchors which failed in the onsite acceptance test were downgraded to carry a lower working load. Additional anchors were added to compensate for the downgrading of some of the existing anchors. The cause of lack of performance is due to the method of installation of ground anchors under high groundwater table conditions. The replacement anchors, which were installed using a full casing during drilling, performed well. The large positive deviations in Figure 3(b) were due to incorrect higher lock-off loads applied at the site. Figure 5(a) shows an example where the measured load cell reading after lock-off was lower than the prescribed lock-off load at the beginning (approximately $80 \%$ of the prescribed lockoff). The load in the anchor registered a slight increase during slab demolition.

Another source of the discrepancies is that the employed vibrating wire load cells with strain gauges were prone to errors when the loads applied are non-concentric. The calibration of the load cells with three strain gauges was carried out in the laboratory in an idealised condition where the loadings were co-axial. As the load cells had no issues during calibration, it was purchased by the instrumentation contractor for use at this site. However, the configuration of the ground anchor system is non-coaxial in the actual site, and can lead to eccentric loads. This problem was picked up by looking into the individual strain gauge readings in the load cell, some of which revealed large distinct magnitudes. Lift-off tests were used to verify all the installed anchors, and additional anchors were installed as part of the mitigation measures. There are several instances in Station B where the load cell readings registered much higher magnitudes, and this had to be investigated, to decide if the stresses have to be relieved. It was found that the anchors were still within both the geotechnical and structural load capacities (considering also the potential for further load increase due to the wall movement). Depending on the design working load and the number of strands installed, there was still a reserve in terms of structural capacity because the strands come in pairs in a U-loop ground anchor.

\subsection{Discussion on the ground anchors in the Kuala Lumpur limestone formation}

For the ground anchors installed in the Kuala Lumpur formation (Figure 4), most of the deviations between measured load cell readings and prescribed lock-off loads in Stations D, E, F and $G$ are not more than $\pm 10 \%$. The higher magnitudes of measured load cell readings in Station E were checked, and these loads were found to be within the geotechnical and structural capacity. It is noted that subsequent loss of load in one of the ground anchors occurred in Station D, and re-stressing was carried out (see Figure 5(b)). The load of the anchor increased with excavation. Experience here also led to the realisation of the importance of determining the appropriate reduction factor for the structural capacity of the tendons due to bending at the U-turn point (Koo 2013). Our experience from the proving tests is that, for the same U-turn radius, tendons with larger diameters may not lead to improvements in the structural capacity, due to the need for greater reduction in capacities due to bending. 


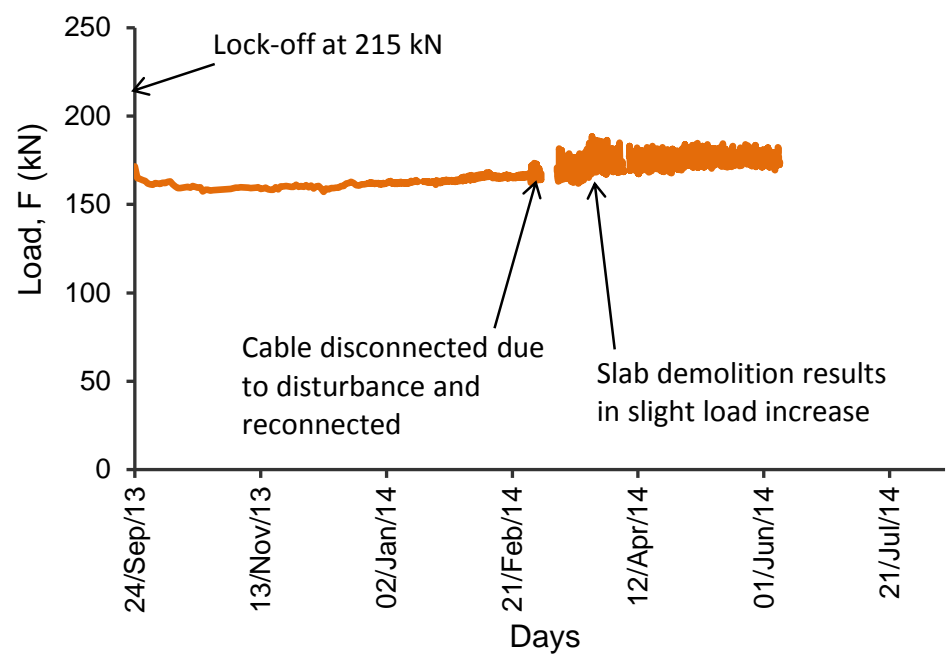

(a)

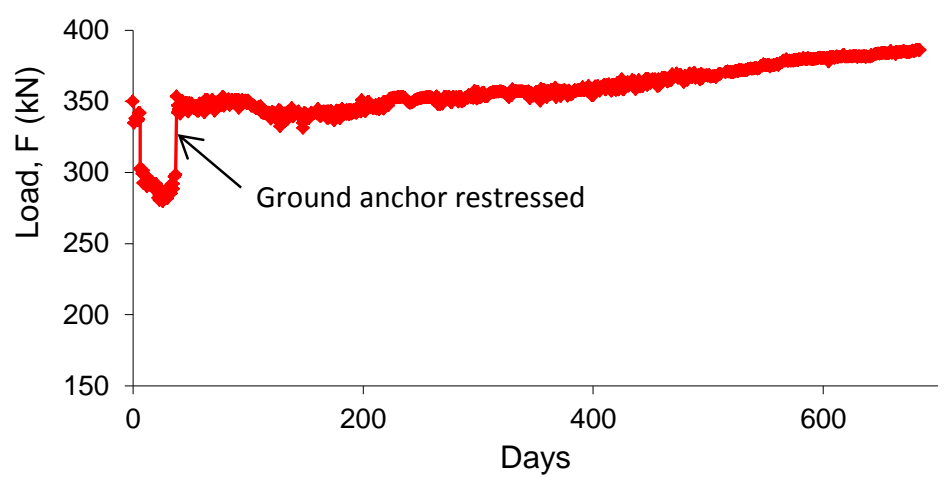

(b)

Figure 5 Example of monitored loads for two ground anchors; (a) monitored loads at lock-off is lower than the prescribed lock-off load at the beginning and increases during slab demolition; (b) load losses was measured and restressed. Subsequent excavation led to load increase in anchors

\section{Comparison between load cell and hydraulic jack}

An important observation in Figures 3 and 4 is that some of the load cell readings registered greater magnitudes than the prescribed lock-off loads at the site. A model test was undertaken to examine the discrepancies between the load cell readings and the prescribed loads from the hydraulic jack for Station B. This exercise also verifies the utilisation of jack loads as reference loads. The hydraulic jack in the model test had been calibrated in a laboratory. As mentioned, the load cell used had only three strain gauges and was prone to error under non-concentric load. The experimental setup is shown in Figure 6, where two load cells are stacked above the hydraulic jack. The readings of the two load cells are shown in Figure 7. A load as high as $500 \mathrm{kN}$ was applied, and the discrepancy between the upper load cell with the hydraulic jack was approximately $10 \%$ (over-prediction), and $-20 \%$ (under-prediction) for the lower load cell. In fact these magnitudes are considered to be conservative and the actual magnitudes experienced at the site would be higher, because the test setup was assembled vertically and in a controlled manner. Some of the sources contributing to discrepancies in practice are as follows:

- Bending of the bearing plate, against which the stressing chair is acting.

- Tendons are strained at different forces due to different lengths.

- High pressures at the corners of the chairs. 


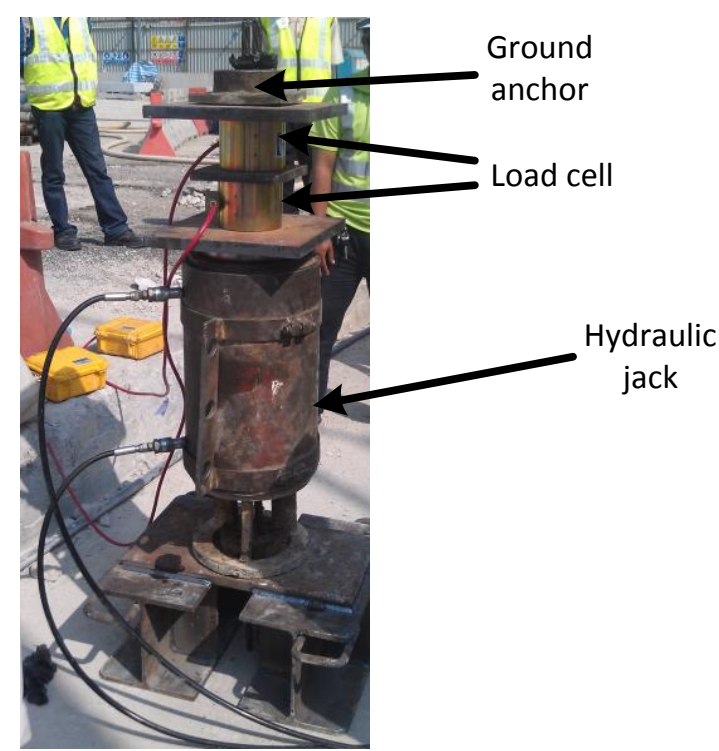

Figure 6 Experimental setup consisting of ground anchor block, tendons, seating chair, two load cells and hydraulic jack for a benchmark test

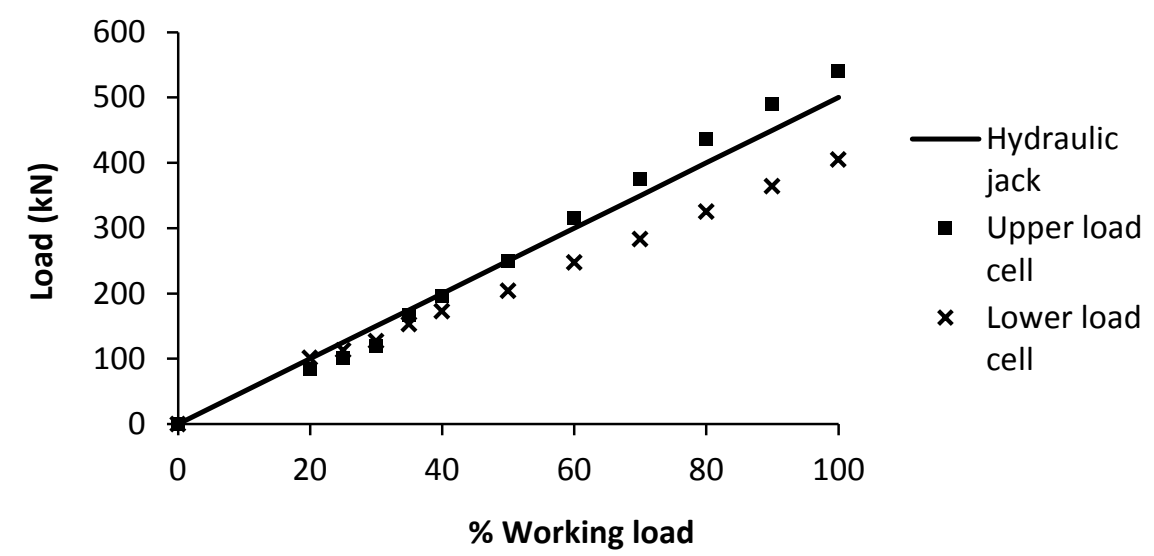

(a)



(b)

Figure 7 Results of comparison between load cell readings and hydraulic jack; (a) upper and lower load cells versus hydraulic jack; (b) discrepancies in terms of percentage 


\section{$4 \quad$ Obtaining the genuine lock-off loss}

Effort was made to measure the actual lock-off load at the site in Station B. A load cell with four strain gauges was used. The monitoring contractor was informed to arrange for the reading of load cell when the ground anchor is stressed and locked-off. This needs to be arranged, otherwise the load cell readings prior to lock-off, i.e. at the prescribed lock off load, are not read. The results are shown in Table 2, and the lock-off loss was found to be approximately $8 \%$.

Table 2 Load cell readings recorded before and after lock-off

\begin{tabular}{lccc}
\hline Activity & $\begin{array}{c}\text { Load cells readings } \\
\text { (kN) }\end{array}$ & $\begin{array}{c}\text { Load changes } \\
\text { (kN) }\end{array}$ & $\begin{array}{c}\text { Percentage difference } \\
\text { (\%) }\end{array}$ \\
\hline Before stressing (free) & 0 & 0 & - \\
After stressing & 253 & 253 & - \\
$\begin{array}{l}\text { After lock off and remove } \\
\text { the jack and chair }\end{array}$ & 233 & -20 & -8.1 \\
\hline
\end{tabular}

Genuine sources of lock-off loss could be induced by:

- The distance required for the wedging-in of wedges into the anchor block.

- Slippage between the tendons and the wedges during lock-off.

The magnitudes of lock-off loss could be checked as to whether they are realistic in terms of displacements. For instance, for a $20 \mathrm{kN}$ of lock-off loss (Table 2), the relaxation in length of the tendons is approximately $4 \mathrm{~mm}$ based on the stiffness that is obtained in Figure 2.

\section{Conclusion}

From our review of different underground stations, it appears that most of the measured load cell readings and the prescribed lock-off loads are within deviation magnitudes of $10 \%$, indicating that the ground anchors are performing according to design. However, for cases in which the deviations are greater than $10 \%$, the measured load cell readings must be reliable so that the engineer can determine correctly the next course of action. Based on the results of the onsite acceptance tests and load cell readings, the engineer must decide whether or not to carry out re-stressing. Depending on the results of re-stressing, the working load of the ground anchor may have to be downgraded.

We found two main sources which can cause the measured load cell readings to deviate from the prescribed lock-off loads:

- The first is that the actual loading condition on the load cell has deviated from the idealised concentric loading condition. This can be detected by reviewing the individual strain gauge readings of the load cell.

- The second source of discrepancy is due to lock-off loss.

Our recommendations are:

- To minimise errors in the load cell readings due to non-concentric loading conditions, load cells with equal number of gauges at any side of the axis should be used. These load cells are more effective at cancelling-off effects of eccentricity. To ensure that the loads are concentric, it is recommended that a spherical seating can be installed on the load cell.

- To determine the potential deviations between the load cell, which is used to measure the loads applied to the ground anchor, and the hydraulic jack, which is used to apply the loads, a model 
test which mimics onsite stressing can be carried out. The magnitude of discrepancy can provide an indication of the influence of non-concentric loading conditions.

- To determine the lock-off loss in practice, the load cell readings prior to lock-off has to be measured, which requires coordination between the contractor installing the ground anchor and instrumentation contractor.

The solutions above can be implemented in construction practice. These measures are important to distinguish the actual lock-off loss from monitoring error, so that a valid assessment of the need for restressing of ground anchors can be carried out.

\section{References}

British Standard 1989, BS 8081:1989: Code of practice for ground anchorage, BSI.

Koo, KS 2013, 'Design and construction of excavation works for Klang Valley Mass Rapid Transit Underground Station at Cochrane, Kuala Lumpur, Malaysia', in Y-J Cui \& F Emeriault (eds), Proceedings of the Fifth International Young Geotechnical Engineers' Conference, IOS Press, Amsterdam, vol. 2, pp. 559-563. 